\title{
Storage of refrigerated raw goat milk affecting the quality of whole milk powder
}

\author{
C. R. Fonseca, ${ }^{*}$ K. Bordin, ${ }^{*}$ A. M. Fernandes,† C. E. C. Rodrigues, ${ }^{*}$ C. H. Corassin, ${ }^{*}$ A. G. Cruz,‡ \\ and C. A. F. Oliveira*1 \\ *Departamento de Engenharia de Alimentos, and \\ †Departamento de Ciências Básicas, Faculdade de Zootecnia e Engenharia de Alimentos, Universidade de São Paulo, Av. Duque de Caxias \\ Norte, 225, CEP 13635-900 Pirassununga, SP, Brazil \\ ‡Departamento de Tecnologia de Alimentos, Faculdade de Engenharia de Alimentos, Universidade Estadual de Campinas, Campinas, SP, Brazil
}

\begin{abstract}
The aim of this study was to evaluate the influence of the growth of lipolytic bacteria in raw goat milk stored under refrigeration for different periods on quality parameters of goat milk powder during its shelf life. Fresh goat milk (100 L) was collected after milking, divided into 3 identical fractions, and stored at $4^{\circ} \mathrm{C}$ for 1,3 , and 5 d. On d 1, 3, and 5, one sample (1 L) was collected and used for microbiological and chemical analysis, and the remaining fraction (almost $30 \mathrm{~L}$ ) was spray dried and stored at $25^{\circ} \mathrm{C}$. Milk powder was submitted to microbiological, chemical, and sensory analysis immediately after production, and on d 60, 120, and 180. Lipolytic psychrotrophic counts and total free fatty acid content did not increase in raw milk during storage. However, peroxide value, caprylic and capric acid concentrations, and total free fatty acid content of milk powder increased during $180 \mathrm{~d}$ of storage, with higher levels found in milk powder manufactured with raw milk stored for $5 \mathrm{~d}$. Capric odor and rancid flavors increased in milk powder during storage, regardless the of storage of raw milk for 1,3 , or 5 d. Heat treatments used during powder processing destroyed lipolytic psychrotrophic bacteria, but did not prevent lipolysis in milk powder. Results of this trial indicate that the storage of raw goat milk at $4^{\circ} \mathrm{C}$ should not exceed $3 \mathrm{~d}$ to preserve the quality of goat milk powder during its shelf life of $180 \mathrm{~d}$.
\end{abstract}

Key words: microbial lipolysis, goat milk, free fatty acid content, spray drying

\section{INTRODUCTION}

Goat milk production plays an important role in the economic well-being of Mediterranean, Middle Eastern, and eastern European countries, as well as developing

Received September 4, 2012.

Accepted March 28, 2013

${ }^{1}$ Corresponding author: carlosaf@usp.br countries in Africa and South America (Dubeuf et al., 2004; Ribeiro and Ribeiro, 2010). In Brazil, interest has grown in intensive dairy goat production and the conversion of milk into products with high added value, aiming at specific, sophisticated market niches of growing demand. Goat milk powder has attracted increasing interest from the dairy industries, as dehydration is an important alternative for milk conservation and can extend goat milk shelf life without changing its nutritional and sensory attributes (Silanikove et al., 2010). This maintains the offer of products to the consumer market throughout the year, and expands the market to more distant regions, with easier and lower-cost transportation (Campos et al., 1998). Small individual production, seasonality, and difficulties in transportation often limit large-scale industrialization of goat milk, making farmers store raw milk at refrigeration temperature for more than $1 \mathrm{~d}$ before processing. This practice causes quality problems for the industry because storage of raw milk at 4 to $7^{\circ} \mathrm{C}$ for some days before processing allows the growth of psychrotrophic bacteria.

Production of enzymes, such as proteases and lipases, by psychrotrophic bacteria can alter the taste and decrease the acceptance of milk by consumers. Lipases hydrolyze milk fat into smaller compounds, called FFA, producing rancid and soapy flavors in dairy products. Lipolytic rancidity of milk can be initiated both by indigenous milk lipases and by microbial lipases. However, only a few of the indigenous milk lipases have a crucial effect on the quality and shelf life of milk and other dairy products (Muir, 1996). The increase in the intensity of capric flavor in stored milk is related to the increase in the amounts of short-chain FFA, which are particularly abundant in the milk of small ruminants, including goats, whose milk contains high contents of caprylic, caproic, and capric acid (Delacroix-Buchet and Lamberet, 2000). Lipases of psychrotrophic bacteria may also produce esters of butyric, isovaleric, and hexanoic acids in the presence of alcohols, which can lead to fruity off-flavor in milk (Delacroix-Buchet and Lamberet, 2000). If the rate of lipolysis in fluid milk is 
high, rancid flavor caused by short-chain FFA may appear in goat milk products (Lamberet et al., 1996). In relation to heat stability of milk lipases, the available data are conflicting. Deeth (1993) stated that the indigenous lipase in bovine milk was completely inactivated by pasteurization. However, Castberg (1992) reported that the native lipase of milk was not completely inactivated after pasteurization $\left(72-75^{\circ} \mathrm{C}\right.$ for $\left.15-20 \mathrm{~s}\right)$, whereas the lipase from bacterial origin survived in UHT milks $\left(130-140^{\circ} \mathrm{C}\right.$ for $\left.2-8 \mathrm{~s}\right)$.

For some time, milk powder was considered relatively inert to biological processes because of its low moisture level, which inhibits the growth of most microorganisms. However, some evidence has shown that changes in milk powder during storage are caused not only by chemical reactions (Stapelfeldt et al., 1997), but also by the activity of enzymes produced by certain microorganisms, such as psychrotrophic bacteria (Celestino et al., 1997). Indeed, the lipoprotein lipase (LPL) activity is lower in goat compared with cow milk, LPL has greater affinity for the fat globules, and the LPL activity is better correlated to spontaneous lipolysis in goat milk (Chilliard et al., 2003). In this context, the aim of this study was to evaluate the influence of the growth of lipolytic bacteria in raw goat milk stored under refrigeration for different periods on the microbiological, biochemical and sensory qualities of goat milk powder during its shelf life.

\section{MATERIALS AND METHODS}

\section{Raw Milk Samples}

About $100 \mathrm{~L}$ of fresh goat milk was collected immediately after milking from the bulk cooling tank of the Faculdade de Zootecnia e Engenharia de Alimentos (University of São Paulo, Brazil) on 3 different occasions. Milk was divided into 3 identical fractions and refrigerated at a controlled temperature $\left(4.0 \pm 0.1^{\circ} \mathrm{C}\right)$ for 1,3 , and $5 \mathrm{~d}$. At these dates, a 1-L sample was used for analysis, and the remaining (almost $30 \mathrm{~L}$ ) was used to manufacture the milk powder.

\section{Milk Powder Production}

The drying process of goat milk was performed in 3 steps. At each day of production (d 1, 3, and 5 of storage), one fraction of stored raw milk was pasteurized $\left(65^{\circ} \mathrm{C}\right.$ for $\left.30 \mathrm{~min}\right)$ and concentrated in a vacuum evaporator at $60^{\circ} \mathrm{C}$ until the TS concentration reached $40 \%$ (wt/wt). Concentrated milk was kept at $60^{\circ} \mathrm{C}$ under constant agitation in a stirrer (Ultra Turrax IKA T25; IKA do Brasil, São Paulo, Brazil) at 20,000 rpm for $20 \mathrm{~min}$, and then dehydrated in a laboratory spray dryer (model SD 5.0; Labmaq do Brasil Ltda., Ribeirão Preto, São Paulo, Brazil). The process conditions were as follows: feed input, $17 \mathrm{~mL} / \mathrm{min}$; compressed air flow, between 40 and $60 \mathrm{~L} / \mathrm{min}$; drying air flow, 12 $\mathrm{m}^{3} / \mathrm{min}$; nozzle atomization opening: $2 \mathrm{~mm}$; input air drying temperature: $147 \pm 2^{\circ} \mathrm{C}$; and output air drying temperature: $115^{\circ} \mathrm{C}$. Milk powder was stored at $25^{\circ} \mathrm{C}$ in metalized polyethylene teraphthalate $\left(70 \mathrm{~g} / \mathrm{cm}^{2}\right)$ packages, under modified atmosphere with less than $2 \%$ residual $\mathrm{O}_{2}$.

\section{Composition of Raw Goat Milk and Goat Milk Powder}

Raw milk composition (moisture, protein, fat, lactose, and ash content) was determined in an automatic milk analyzer (Boecolac; Boeckel \& Co., Hamburg, Germany) that was previously calibrated. The composition of powder samples (moisture, protein, fat, lactose, and ash content) was determined according to AOAC International (1995).

\section{Microbiological Analyses}

Microbiological analyses of raw goat milk and milk powder were performed according to the Compendium of Methods for the Microbiological Examination of Foods (APHA, 2001). Mesophilic bacteria were counted in plate count agar (Merck, Rio de Janeiro, Brazil) after incubation at $37^{\circ} \mathrm{C}$ for $48 \mathrm{~h}$, and lipolytic psychrotrophic bacteria were counted in tributyrin agar (Merck) after $10 \mathrm{~d}$ of incubation at $7^{\circ} \mathrm{C}$. Total coliforms and Escherichia coli most probable number (MPN) per milliliter were analyzed in multiple tubes containing Brilliant Green broth (Oxoid Brasil Ltda., São Paulo, Brazil) and lauryl tryptose sulfate broth with 4-methylumbelliferyl $\beta$-D-glucuronide (LST-MUG; Merck), respectively, after incubation at $37^{\circ} \mathrm{C}$ for $48 \mathrm{~h}$. For E. coli counts, tubes were exposed to UV light (365 $\mathrm{nm})$ for the presence of fluorescence.

\section{Analysis of Lipolytic Activity}

Total FFA content was determined according to Deeth et al. (1975). Exactly $4 \mathrm{~mL}$ of milk was added to a mix of isopropanol:petroleum ether: $\mathrm{H}_{2} \mathrm{SO}_{4}$, after titration with methanolic $\mathrm{KOH}$. Results were expressed in $\mathrm{mEq} / \mathrm{kg}$ of milk. Individual FFA (C6, C8, C10, C12, C14, C16, and C18:0) were analyzed according to De Jong and Badings (1990). Lipid extraction was carried out by mixing $10 \mathrm{~mL}$ of milk with ethanol $(10 \mathrm{~mL})$ and $1 \mathrm{~mL}$ of $\mathrm{H}_{2} \mathrm{SO}_{4}(2.5 \mathrm{~mol} / \mathrm{L})$. Extraction was carried out with $15 \mathrm{~mL}$ of an ether/heptane $(1: 1, \mathrm{vol} / \mathrm{vol})$ solution in a 50 -mL screw cap centrifuge tube. After centrifugation at $1,000 \times g$ for $3 \mathrm{~min}$ at $25^{\circ} \mathrm{C}$, the upper layer was 
Table 1. Composition (means $\pm \mathrm{SE}$ ) of raw goat milk stored for 1,3 , and $5 \mathrm{~d}$ at $4^{\circ} \mathrm{C}$

\begin{tabular}{lrrr}
\hline & \multicolumn{3}{c}{ Days of storage $^{1}$} \\
\cline { 2 - 4 } Composition (\%) & \multicolumn{1}{c}{1} & \multicolumn{1}{c}{3} \\
\hline Moisture & $88.3 \pm 0.2$ & $88.1 \pm 0.2$ & $58.3 \pm 0.3$ \\
TS & $11.7 \pm 0.2$ & $11.9 \pm 0.2$ & $11.7 \pm 0.3$ \\
CP & $3.1 \pm 0.0$ & $3.1 \pm 0.0$ & $3.1 \pm 0.0$ \\
Fat & $3.4 \pm 0.2$ & $3.5 \pm 0.1$ & $3.4 \pm 0.3$ \\
Lactose & $4.5 \pm 0.0$ & $4.5 \pm 0.0$ & $4.5 \pm 0.0$ \\
Ash & $0.7 \pm 0.0$ & $0.7 \pm 0.0$ & $0.7 \pm 0.0$ \\
\hline
\end{tabular}

${ }^{1}$ Not significant $(P>0.05)$.

transferred to a 100-mL conical flask provided with a cap containing $1 \mathrm{~g}$ of anhydrous $\mathrm{Na}_{2} \mathrm{SO}_{4}$ to adsorb the residual water. The extraction procedure was repeated twice with $10 \mathrm{~mL}$ of ether/heptane (1:1, vol/vol).

Free FA isolation was carried out in $6-\mathrm{mL}$ aminopropyl columns (Strata; Phenomenex Inc., Torrance, $\mathrm{CA}$ ). The column was first conditioned with $10 \mathrm{~mL}$ of heptane, and then the lipid extract was added to the column. Neutral lipids were eluted from the column with chloroform:2-propanol (2:1, vol/vol). Free FA were eluted with $2.5 \mathrm{~mL}$ of diethyl ether containing $2 \%$ formic acid. All elutions were carried out under vacuum. Free FA extract was stored at $-18^{\circ} \mathrm{C}$ until analysis.

Exactly $1 \mu \mathrm{L}$ of the extract was splitless injected into a gas chromatograph with flame ionization detector (GC-FID; model GC 2010 AF; Shimadzu Corp., Kyoto, Japan) with an automatic injector (model AOC 20i; Shimadzu Corp.) and a Phenomenex ZB-FFAP capillary (nitroterephthalic acid-modified polyethylene glycol $)$ column $(30 \mathrm{~m} \times 0.32-\mathrm{mm}$ i.d. $\times 0.25-\mu \mathrm{m}$ film thickness; Phenomenex Inc.). Helium was the carrier gas and the flow rate used in the experiment was 0.89 $\mathrm{mL} / \mathrm{min}$. Direct injection was done at an oven temperature of $65^{\circ} \mathrm{C}$, raised to $240^{\circ} \mathrm{C}$ at a $10^{\circ} \mathrm{C} / \mathrm{min}$ rate, and finally kept at $240^{\circ} \mathrm{C}$ for $20 \mathrm{~min}$. The components were identified by comparison against retention times of pure compounds (C2:0, C4:0, C6:0, C8:0, C10:0, C12:0, C14:0, C16:0, and C18:0 purified standards from Sigma-Aldrich, St. Louis, MO), and quantification of individual FFA in samples was performed using the external standard method by measuring peak areas of samples and plotting them against the peak areas of purified standards. Results were expressed as milligrams per liter of milk.

Milk powder samples were reconstituted at $10 \%$ in distilled water (wt/wt) for total and individual FFA content analysis. After that, reconstituted samples were analyzed following the same procedures described for raw goat milk samples. Results were expressed as $\mathrm{mEq} /$ $\mathrm{kg}$ and $\mathrm{mg} / 100 \mathrm{~g}$ of milk powder, respectively, for total and individual FFA.

\section{Fat Oxidation of Milk Powder}

Fat oxidation was measured by measuring the peroxide value according to AOAC International (1995).

\section{Sensory Analysis}

Seven trained panelists evaluated sweet odor and taste, cooked odor and flavor, capric odor and flavor, and rancid flavor in reconstituted goat milk (12\%) samples using a nonstructured scale from 0 (no intensity) to 10 (strong intensity), according to Stone and Sidel (1985). Training sessions were conducted for $4 \mathrm{~h}$ per week for $16 \mathrm{wk}$, totaling $64 \mathrm{~h}$ of training. Milk was rehydrated with water at $50^{\circ} \mathrm{C}$ and the solution was mixed with a stirrer for 5 min at 1,000 rpm. Flasks with the samples were capped and cooled to $25^{\circ} \mathrm{C}$ for sensory analysis.

\section{Statistical Analysis}

The experiment had a complete randomized design with factorial arrangement (3 raw milk storage times, 4 milk powder storage times, and 3 repetitions of the experiment). Statistical analysis was performed using PROC GLM of SAS software (SAS Institute, 2002). Stepwise linear regression was performed by orthogonal contrast. A $P$-value below 0.5 was considered as significant.

\section{RESULTS AND DISCUSSION}

\section{Raw Milk}

Composition and Microbiological Changes of Raw Milk During Storage. The results of raw goat milk composition during cold storage are shown in Table 1 . The storage period did not affect $(P>0.05)$ milk composition. Similar results were found in many other studies around the world (de Albuquerque Brasil et al., 2000; Fekadu et al., 2005; Kondyli et al., 2012). 
Table 2. Microbiological quality (means $\pm \mathrm{SE}$ ) of raw goat milk stored for 1,3 , and $5 \mathrm{~d}$ at $4^{\circ} \mathrm{C}$

\begin{tabular}{lccc}
\hline & \multicolumn{3}{c}{ Days of storage $^{2}$} \\
\cline { 2 - 4 } Microorganism $^{1}$ & 1 & 3 & 5 \\
\hline Mesophiles (log cfu/mL) & $5.6 \pm 0.8$ & $5.8 \pm 0.2$ & $6.3 \pm 0.7$ \\
Lipolytic psychrotrophs $(\log \mathrm{cfu} / \mathrm{mL})$ & $4.7 \pm 0.9$ & $5.7 \pm 0.1$ & $6.3 \pm 0.4$ \\
Coliforms at $35^{\circ} \mathrm{C}(\log \mathrm{MPN} / \mathrm{mL})$ & $2.4 \pm 0.3$ & $2.5 \pm 0.7$ & $2.3 \pm 0.9$ \\
Escherichia coli $(\log \mathrm{MPN} / \mathrm{mL})$ & $1.5 \pm 0.2$ & $1.5 \pm 0.2$ & $1.4 \pm 0.2$ \\
\hline
\end{tabular}

${ }^{1} \mathrm{MPN}=$ most probable number.

${ }^{2}$ Not significant $(P>0.05)$

Counts of mesophilic bacteria between the first and fifth day of storage increased from $4.3 \times 10^{5}$ to $3.6 \times$ $10^{6} \mathrm{cfu} / \mathrm{mL}$ (Table 2). The Brazilian regulation for raw goat milk (Ministério da Agricultura e Pecuária, 1999) determines maximum counts of $5.0 \times 10^{5} \mathrm{cfu} / \mathrm{mL}$ for mesophilic bacteria; hence, the experimental raw milks complied with the maximum permitted level during $3 \mathrm{~d}$ of storage at $4^{\circ} \mathrm{C}$. Lipolytic psychrotrophic counts also increased during storage, and no effect $(P>0.05)$ was observed of length of storage on coliforms or E. coli counts in milks during $5 \mathrm{~d}$ of storage. The microbiological quality of raw milk is one of the most important factors for keeping the chemical and sensory characteristics of dairy products (Samaržija et al., 2012). High initial microbiological counts are strongly correlated with the spoilage of products throughout the shelf life (Celestino et al., 1997). However, the optimization of time and temperature during storage is of particular importance to avoid an increase in psychrotrophic bacteria in raw milk (Perin et al., 2012). Zeng et al. (2007) observed that goat milk in farm bulk tanks that met the US regulatory criteria for mesophilic count and SCC had low quality after $5 \mathrm{~d}$ of storage because of the growth of psychrotrophic bacteria.

Lipolysis in Raw Milk During Storage. The individual concentrations of FFA in raw goat milk during storage showed the predominance of long-chain FFA (C14-C18), such as palmitic (C16:0) and stearic acids (C18:0; Table 3). Kondyli and Katsiari (2002) also reported the predominance of long-chain FFA in goat milk. Butyric acid (C4:0) was not detected in any sample. Likewise, caproic (C6:0) and caprylic (C8:0) acids were not detected in samples stored for $1 \mathrm{~d}$. Detection limits for butyric, caproic, and caprylic acid were $0.3,0.2$, and $0.2 \mathrm{mg} / \mathrm{L}$, respectively. During raw milk storage, changes in short- and medium-chain FFA concentrations (C6-C12) were observed, although values obtained on the fifth day were much lower than those reported by Pereira et al. (2008) for caproic (8.5 to $13.5 \mathrm{mg} / \mathrm{L})$, caprylic $(9.2$ to $20.4 \mathrm{mg} / \mathrm{L})$, and capric acids $(18.5$ to $61.1 \mathrm{mg} / \mathrm{L}$ ) in raw goat milk samples. In spite of the numeric differences in individual levels of FFA during storage, mainly in the concentrations of palmitic and stearic acids, no significant effect $(P>$ 0.05 ) was observed of the length of raw milk storage on the FFA profile of raw milk fat, as well as on the sum of FFA analyzed in the study $(P>0.05)$.

Significant $(P<0.01)$ correlations were observed between the FFA content and the counts of mesophilic or lipolytic bacteria ( $\mathrm{r}=0.87$ and 0.81 , respectively). Lipolysis is the most important consequence of prolonged refrigeration of milk (Vianna et al., 2012). Milk lipolysis may be caused by natural lipases in milk or psychrotrophic microorganisms during cold storage, thus leading to an increase in FFA content in milk (Chen et al., 2003) and, consequently, to increased offflavors in goat milk products.

\section{Milk Powders}

Composition of Milk Powder. The composition of milk powder is shown in Table 4. Moisture contents of all

Table 3. Individual FFA profile (means $\pm \mathrm{SE} ; \mathrm{mg} / \mathrm{L}$ of milk) of raw goat milk stored for 1,3 , and $5 \mathrm{~d}$ at $4^{\circ} \mathrm{C}$

\begin{tabular}{lccc}
\hline & \multicolumn{3}{c}{ Days of storage $^{1}$} \\
\cline { 2 - 4 } FFA & 1 & 3 & 5 \\
\hline Caproic acid (C6) & $0.0 \pm 0.0$ & $1.3 \pm 0.1$ & $0.5 \pm 0.1$ \\
Caprylic acid (C8) & $0.0 \pm 0.0$ & $0.8 \pm 0.1$ & $0.3 \pm 0.1$ \\
Capric acid (C10) & $0.6 \pm 0.1$ & $2.1 \pm 0.1$ & $2.1 \pm 0.2$ \\
Lauric acid (C12) & $0.4 \pm 0.1$ & $1.6 \pm 0.1$ & $2.2 \pm 0.2$ \\
Myristic acid (C14) & $1.4 \pm 0.1$ & $2.8 \pm 0.2$ & $2.6 \pm 0.2$ \\
Palmitic acid (C16) & $5.1 \pm 0.2$ & $10.1 \pm 0.5$ & $11.0 \pm 0.7$ \\
Stearic acid (C18) & $6.3 \pm 0.2$ & $8.1 \pm 1.1$ & $13.7 \pm 1.0$ \\
\hline
\end{tabular}

${ }^{1}$ Not significant $(P>0.05)$. 
Table 4. Composition (means $\pm \mathrm{SE}$ ) of goat milk powder stored for up to $180 \mathrm{~d}$ at $25^{\circ} \mathrm{C}$ according to the length of raw milk storage at $4^{\circ} \mathrm{C}$

\begin{tabular}{|c|c|c|c|c|c|}
\hline \multirow[b]{2}{*}{ Composition (\%) } & \multirow{2}{*}{$\begin{array}{l}\text { Days of storage } \\
\text { of raw milk }\end{array}$} & \multicolumn{4}{|c|}{ Days of storage of milk powder } \\
\hline & & 0 & 60 & 120 & 180 \\
\hline \multirow[t]{3}{*}{ Moisture } & 1 & $2.0 \pm 0.5$ & $2.0 \pm 0.5$ & $1.9 \pm 0.4$ & $1.8 \pm 0.3$ \\
\hline & 3 & $1.8 \pm 0.1$ & $2.0 \pm 0.7$ & $1.5 \pm 0.3$ & $1.9 \pm 0.4$ \\
\hline & 5 & $1.7 \pm 0.1$ & $1.9 \pm 0.7$ & $1.9 \pm 0.4$ & $1.8 \pm 0.3$ \\
\hline \multirow[t]{3}{*}{$\mathrm{CP}^{1}$} & 1 & $24.7 \pm 0.1$ & $24.3 \pm 0.1$ & $24.3 \pm 0.2$ & $24.5 \pm 0.3$ \\
\hline & 3 & $24.5 \pm 0.2$ & $24.3 \pm 0.3$ & $24.4 \pm 0.3$ & $24.5 \pm 0.2$ \\
\hline & 5 & $24.3 \pm 0.3$ & $24.5 \pm 0.2$ & $24.6 \pm 0.3$ & $24.3 \pm 0.2$ \\
\hline \multirow[t]{3}{*}{ Fat } & 1 & $31.8 \pm 0.5$ & $28.5 \pm 1.0$ & $28.6 \pm 0.4$ & $28.2 \pm 0.3$ \\
\hline & 3 & $32.1 \pm 0.7$ & $29.1 \pm 0.6$ & $28.6 \pm 0.4$ & $28.3 \pm 0.3$ \\
\hline & 5 & $31.3 \pm 0.7$ & $28.7 \pm 1.1$ & $28.4 \pm 0.3$ & $28.3 \pm 0.3$ \\
\hline \multirow[t]{3}{*}{ Lactose } & 1 & $37.3 \pm 1.1$ & $38.5 \pm 1.6$ & $38.7 \pm 0.8$ & $39.0 \pm 0.6$ \\
\hline & 3 & $37.1 \pm 0.6$ & $37.9 \pm 0.9$ & $39.3 \pm 0.9$ & $39.1 \pm 0.7$ \\
\hline & 5 & $37.1 \pm 0.3$ & $38.1 \pm 0.9$ & $38.7 \pm 0.2$ & $39.3 \pm 0.3$ \\
\hline \multirow[t]{3}{*}{ Ash } & 1 & $6.3 \pm 0.0$ & $6.3 \pm 0.1$ & $6.3 \pm 0.1$ & $6.3 \pm 0.1$ \\
\hline & 3 & $6.3 \pm 0.0$ & $6.2 \pm 0.1$ & $6.2 \pm 0.1$ & $6.1 \pm 0.1$ \\
\hline & 5 & $6.2 \pm 0.1$ & $6.3 \pm 0.1$ & $6.2 \pm 0.1$ & $6.3 \pm 0.1$ \\
\hline
\end{tabular}

${ }^{1}$ Significant $(P<0.05)$.

treatments were lower than results reported elsewhere (Campos et al., 1998; Diniz et al., 2005), and also lower than the maximum limit established by the Brazilian regulation for the quality of milk powder (Ministério da Agricultura do Abastecimento e da Reforma Agrária, 1996). The absence of effects of the length of storage on the moisture of raw milk before processing, and of milk powder $(P>0.05)$ suggest that the flexible packaging used was efficient to protect the powder from external moisture during the 6-mo storage.

Protein content had little variation among treatments during storage of milk powder, although an interaction $(P<0.05)$ between the length of storage of raw milk and milk powder was observed. The fat contents of milk powders were similar to the results described in Diniz et al. (2005). A linear decrease $(P<0.01)$ was observed in fat content during storage of milk powder, although no effect of the length of storage of raw milk $(P>0.05)$ was observed on fat content of milk powder. Celestino et al. (1997) also reported a significant effect of the length of storage of cow milk powder on fat content during $8 \mathrm{mo}$ of storage. Lactose and ash contents were not affected $(P>0.05)$ by the length of storage of raw milk or milk powder.

Microbiological Quality of Milk Powder. A linear effect was observed according to the length of storage of raw milk $(P<0.05)$, in which milk powder obtained from raw milk stored for $5 \mathrm{~d}$ showed higher mesophilic counts (Table 5). However, no effect of the length of storage of the powder $(P>0.05)$ was observed on mesophilic counts, and no significant interaction $(P$ $>0.05$ ) between the length of storage of raw milk and milk powder was observed in mesophilic counts. As expected, lipolytic psychrotrophs were destroyed by the heat treatments used in the production of milk powder. Total coliforms and E. coli were not detected in milk powder samples, confirming that good practices during powder manufacturing were able to destroy undesirable potentially pathogenic microorganisms.

Lipolysis in Milk Powder During Storage. The averages of total FFA in goat milk powder samples are presented in Table 6 . The highest contents were found in powders stored for longer periods and obtained from raw milk that was also stored for a longer period (5 d). Celestino et al. (1997) reported an increase in FFA content during the storage of cow whole milk powder stored for $180 \mathrm{~d}$ at $25^{\circ} \mathrm{C}$. Similar to our results, the authors found that FFA in milk powder also increased with the length of storage of raw milk stored for $4 \mathrm{~d}$ at $4^{\circ} \mathrm{C}$, but no interaction between these effects was reported.

Individual FFA profile (Table 7) showed greater concentrations of palmitic and stearic acids. Lauric acid was also present in greater amounts when compared with short-chain FFA, and in greater concentrations than myristic acid. Butyric acid (C4) was not detected in any of the samples. The length of storage of raw milk presented a linear effect on the amounts of caprylic and myristic acids, and a quadratic effect on the amount of capric acid. A linear increase in the amounts of caprylic and capric acids was observed throughout the storage period of milk powder. Higher $(P<0.05)$ FFA levels were observed in milk powders manufactured with raw milk stored for 5 d. Páez et al. (2006) reported a $21 \%$ increase in lauric acid along with a $24 \%$ reduction in palmitic acid of cow milk powder during 6-mo storage.

Oxidation of Milk Powder Fat During Storage. Peroxide values obtained in milk powders are presented 
Table 5. Microbiological quality of goat milk powder stored for up to $180 \mathrm{~d}$ at $25^{\circ} \mathrm{C}$ according to the length of raw milk storage at $4^{\circ} \mathrm{C}$

\begin{tabular}{lccccc}
\hline & & \multicolumn{4}{c}{ Days of storage of milk powder } \\
\cline { 3 - 6 } Microorganism $^{1}$ & $\begin{array}{c}\text { Days of storage } \\
\text { of raw milk }\end{array}$ & 0 & 60 & 120 & 180 \\
\hline Mesophiles $^{2}(\log \mathrm{cfu} / \mathrm{g})$ & 1 & 2.5 & 2.5 & 2.8 & 2.5 \\
& 3 & 3.1 & 3.2 & 3.3 & 3.0 \\
& 5 & 3.6 & 3.8 & 3.3 & 3.5 \\
Lipolytic psychrotrophs (cfu/g) & 1 & $<10$ & $<10$ & $<10$ & $<10$ \\
& 3 & $<10$ & $<10$ & $<10$ & $<10$ \\
Coliforms at $35^{\circ} \mathrm{C}(\mathrm{MPN} / \mathrm{g})$ & 5 & $<10$ & $<10$ & $<10$ & $<10$ \\
& 1 & $<3$ & $<3$ & $<3$ & $<3$ \\
& 3 & $<3$ & $<3$ & $<3$ & $<3$ \\
Escherichia coli $(\mathrm{MPN} / \mathrm{g})$ & 5 & $<3$ & $<3$ & $<3$ & $<3$ \\
& 1 & $<3$ & $<3$ & $<3$ & $<3$ \\
& 3 & $<3$ & $<3$ & $<3$ & $<3$ \\
& 5 & $<3$ & $<3$ & $<3$ & $<3$ \\
\hline
\end{tabular}

${ }^{1} \mathrm{MPN}=$ most probable number.

${ }^{2}$ Significant $(P<0.05)$.

in Table 8. The longer the storage of raw milk or milk powders, the higher the amount of peroxides in the powders $(P<0.05)$. The storage of raw milk for $5 \mathrm{~d}$ led to higher peroxide values $(P<0.05)$ in milk powders compared with other storage times of raw milk. The presence of fat-oxidizing products such as peroxides and aldehydes are important factors that have a significant effect on the sensory quality of milk powder. Our findings are similar to those reported by Campos et al. (1998), who evaluated the oxidation of whole milk powder stored in packages (similar to those used in the current study) and stored in an atmosphere with $4 \%$ of residual $\mathrm{O}_{2}$.

Baldwin et al. (1991) reported peroxide values between 0.03 and $3 \mathrm{mEq} / \mathrm{kg}$ of fat in milk powder stored for 18 mo under normal atmosphere. Because peroxides are products of primary lipid oxidation, they generally reach a maximum level within a certain period, and then tend to decrease due to the formation of secondary oxidation products (McCluskey et al., 1997). In the present study, peroxide values found indicated a low rate of oxidation of fat present in milk powder, which is in agreement with the data reported by PanfilKuncewicz et al. (2005) on the ability of oxygen and FFA from lipolysis to induce oxidizing changes in milk.

Sensory Analysis of Reconstituted Milk. Sensory grades of reconstituted milk powders are shown in Table 9. The length of storage of milk powder had a linear effect $(P<0.01)$ on the capric odor grades. Accordingly, a significant positive correlation $(P<0.01)$ was also observed between the intensity of capric odor in reconstituted milk samples and the concentrations of capric or caprylic acids in milk powder $(\mathrm{r}=0.79$ and 0.89 , respectively). The most intense flavors evidenced by the panelists were sweet taste and capric flavor, although no significant effects $(P>0.05)$ of the length of storage of raw milk or milk powder were observed on this attribute. Also, no effect was detected for cooked flavor in reconstituted milk samples $(P>0.05)$. The absence of effects may be explained by the fact that the differences in FFA concentrations were not sufficient to cause a sensory difference in the powders. However, a significant positive correlation $(P<0.05)$ was observed between the capric flavor grades and the concentrations

Table 6. Total FFA content (means $\pm \mathrm{SE} ; \mathrm{mEq} / \mathrm{kg}$ of milk powder) of goat milk powder stored for up to 180 $\mathrm{d}$ at $25^{\circ} \mathrm{C}$ according to the length of raw milk storage at $4^{\circ} \mathrm{C}$

\begin{tabular}{|c|c|c|c|c|}
\hline \multirow[b]{2}{*}{ Item } & \multicolumn{4}{|c|}{ Days of storage of milk powder } \\
\hline & 0 & 60 & 120 & 180 \\
\hline \multicolumn{5}{|l|}{ Days of storage of raw milk } \\
\hline 1 & $5.9 \pm 1.8$ & $5.1 \pm 2.6$ & $5.6 \pm 1.8$ & $6.3 \pm 0.9$ \\
\hline 3 & $6.6 \pm 0.8$ & $7.0 \pm 3.1$ & $6.7 \pm 0.8$ & $7.2 \pm 0.9$ \\
\hline 5 & $10.1 \pm 0.2$ & $9.5 \pm 0.8$ & $10.0 \pm 1.5$ & $15.4 \pm 2.6$ \\
\hline \multicolumn{5}{|l|}{ Probability ( $P$-value) } \\
\hline Raw milk storage (A) & \multicolumn{4}{|c|}{0.0001} \\
\hline Powder milk storage (B) & \multicolumn{4}{|c|}{0.0012} \\
\hline $\mathrm{A} \times \mathrm{B}$ & \multicolumn{4}{|c|}{0.0066} \\
\hline
\end{tabular}


Table 7. Individual FFA profile (means $\pm \mathrm{SE} ; \mathrm{mg} / 100 \mathrm{~g}$ of powder) of goat milk powder stored for up to $180 \mathrm{~d}$ at $25^{\circ} \mathrm{C}$, according to the length of raw milk storage at $4^{\circ} \mathrm{C}$

\begin{tabular}{|c|c|c|c|c|c|c|c|c|}
\hline FFA & $\begin{array}{c}\text { Days of raw } \\
\text { milk storage }(\mathrm{A})\end{array}$ & \multicolumn{4}{|c|}{ Days of milk powder storage (B) } & \multicolumn{3}{|c|}{ Probability ( $P$-value) } \\
\hline \multirow{2}{*}{ Caproic acid (C6) } & 3 & $2.9 \pm 0.1$ & $2.1 \pm 0.8$ & $2.1 \pm 0.2$ & $2.4 \pm 0.3$ & & 0.49 & 0.85 \\
\hline & 5 & $2.5 \pm 0.1$ & $2.6 \pm 0.2$ & $2.9 \pm 0.1$ & $2.7 \pm 0.2$ & & & \\
\hline \multirow[t]{2}{*}{ Caprylic acid (C8) } & 1 & $1.6 \pm 0.3$ & $1.7 \pm 0.1$ & $2.0 \pm 0.3$ & $2.2 \pm 0.2$ & & & \\
\hline & 3 & $1.3 \pm 0.3$ & $1.3 \pm 0.4$ & $2.6 \pm 0.0$ & $2.4 \pm 0.2$ & $0.0005^{*}$ & $0.0001^{*}$ & 0.28 \\
\hline \multirow{2}{*}{ Capric acid (C10) } & 3 & $1.3 \pm 0.1$ & $1.4 \pm 0.1$ & $1.7 \pm 0.2$ & $1.8 \pm 0.1$ & $<0.0001^{*}$ & $<0.0001^{*}$ & 0.15 \\
\hline & 5 & $1.3 \pm 0.1$ & $1.3 \pm 0.4$ & $1.5 \pm 0.4$ & $1.7 \pm 0.1$ & & & \\
\hline \multirow[t]{3}{*}{ Lauric acid (C12) } & 1 & $6.2 \pm 0.1$ & $7.1 \pm 0.6$ & $8.8 \pm 0.2$ & $10.0 \pm 0.5$ & & & \\
\hline & 3 & $5.3 \pm 0.1$ & $6.4 \pm 0.2$ & $6.6 \pm 0.5$ & $8.7 \pm 0.2$ & 0.37 & 0.0744 & 0.997 \\
\hline & 5 & $5.5 \pm 0.2$ & $5.1 \pm 0.4$ & $7.3 \pm 0.1$ & $8.2 \pm 0.3$ & & & \\
\hline \multirow[t]{2}{*}{ Myristic acid (C14) } & 1 & $2.8 \pm 0.1$ & $2.7 \pm 1.0$ & $2.6 \pm 0.5$ & $2.8 \pm 0.5$ & & & \\
\hline & 3 & $2.6 \pm 0.9$ & $3.3 \pm 0.5$ & $3.1 \pm 0.8$ & $3.4 \pm 0.3$ & $0.012^{*}$ & 0.3241 & 0.78 \\
\hline \multirow{2}{*}{ Stearic acid (C18) } & 3 & $15.1 \pm 1.3$ & $13.9 \pm 1.7$ & $15.8 \pm 1.7$ & $17.3 \pm 1.2$ & 0.52 & 0.94 & 0.47 \\
\hline & 5 & $15.6 \pm 3.9$ & $14.6 \pm 2.2$ & $14.1 \pm 1.5$ & $15.8 \pm 4.7$ & & & \\
\hline
\end{tabular}

*Significant $(P<0.05)$.

of capric or caprylic acids in milk powder $(\mathrm{r}=0.83$ and 0.67 , respectively).

Rancid flavor showed very low intensity in reconstituted milk powders (almost none). The highest value was observed in milk powder obtained from raw milk stored for $5 \mathrm{~d}$, and then stored for $180 \mathrm{~d}$, a fact that is in line with the highest amount of total FFA in milk powder (Table 6$)$. No effect $(P>0.05)$ was observed of the storage period of raw milk on the intensity of rancid flavor in reconstituted milk, although a linear effect $(P<0.01)$ was observed of the length of storage of milk powder on this attribute. Chen et al. (2003) reported that the threshold for detection of rancid flavor as defined by lipolysis in milk is approximately $55 \mathrm{mg} / \mathrm{L}$ of short- and medium-chain FFA in milk. In our study, the highest level of C6 to C12 FFA found in milk powders was $19.3 \mathrm{mg} / \mathrm{L}$, which is much lower than the threshold cited above, and this difference could explain the almost nonexistent intensity of rancid taste detected by panelists in the reconstituted milk. Accordingly, significant positive correlations $(P<0.01)$ were also observed between rancid flavor intensity in reconstituted milk and the amounts of caprylic or capric acids in milk powder ( $\mathrm{r}=0.70$ and 0.81 , respectively), and the peroxide values of milk powder, hence indicating that oxidation of milk fat also contributes to the development of compounds that enhance the rancid flavor in milk powder.

According to Champagne et al. (1994), raw milk should generally have psychrotrophic counts above 1.0 $\times 10^{6} \mathrm{cfu} / \mathrm{mL}$ for changes in milk odor and taste to become noticeable. Therefore, low counts of psychrotrophic bacteria in milk is an important aspect for the quality of dairy products, as its growth can be highly

Table 8. Peroxide value (means $\pm \mathrm{SE} ; \mathrm{mEq} / \mathrm{kg}$ of fat) of goat milk powder stored for up to $180 \mathrm{~d}$ at $25^{\circ} \mathrm{C}$ according to length of raw milk storage at $4^{\circ} \mathrm{C}$

\begin{tabular}{lcccc}
\hline & \multicolumn{4}{c}{ Days of storage of milk powder } \\
\cline { 2 - 5 } Item & 0 & 60 & 120 & 180 \\
\hline Days of storage of raw milk & $0.1 \pm 0.1$ & $0.1 \pm 0.1$ & $0.3 \pm 0.1$ & $0.4 \pm 0.2$ \\
1 & $0.2 \pm 0.1$ & $0.3 \pm 0.4$ & $0.5 \pm 0.2$ & $0.6 \pm 0.2$ \\
3 & $0.1 \pm 0.0$ & $0.5 \pm 0.3$ & $0.7 \pm 0.2$ & $0.7 \pm 0.4$ \\
5 & & & 0.0002 & \\
Probability (P-value) & \multicolumn{3}{c}{0.0001} \\
Raw milk storage (A) & \multicolumn{3}{c}{0.2440} \\
Powder milk storage (B) & &
\end{tabular}


Table 9. Sensory grades (means $\pm \mathrm{SE}$ ) of reconstituted $(12 \%)$ goat milk powder stored for up to $180 \mathrm{~d}$ at $25^{\circ} \mathrm{C}$ according to the length of raw milk storage at $4^{\circ} \mathrm{C}$

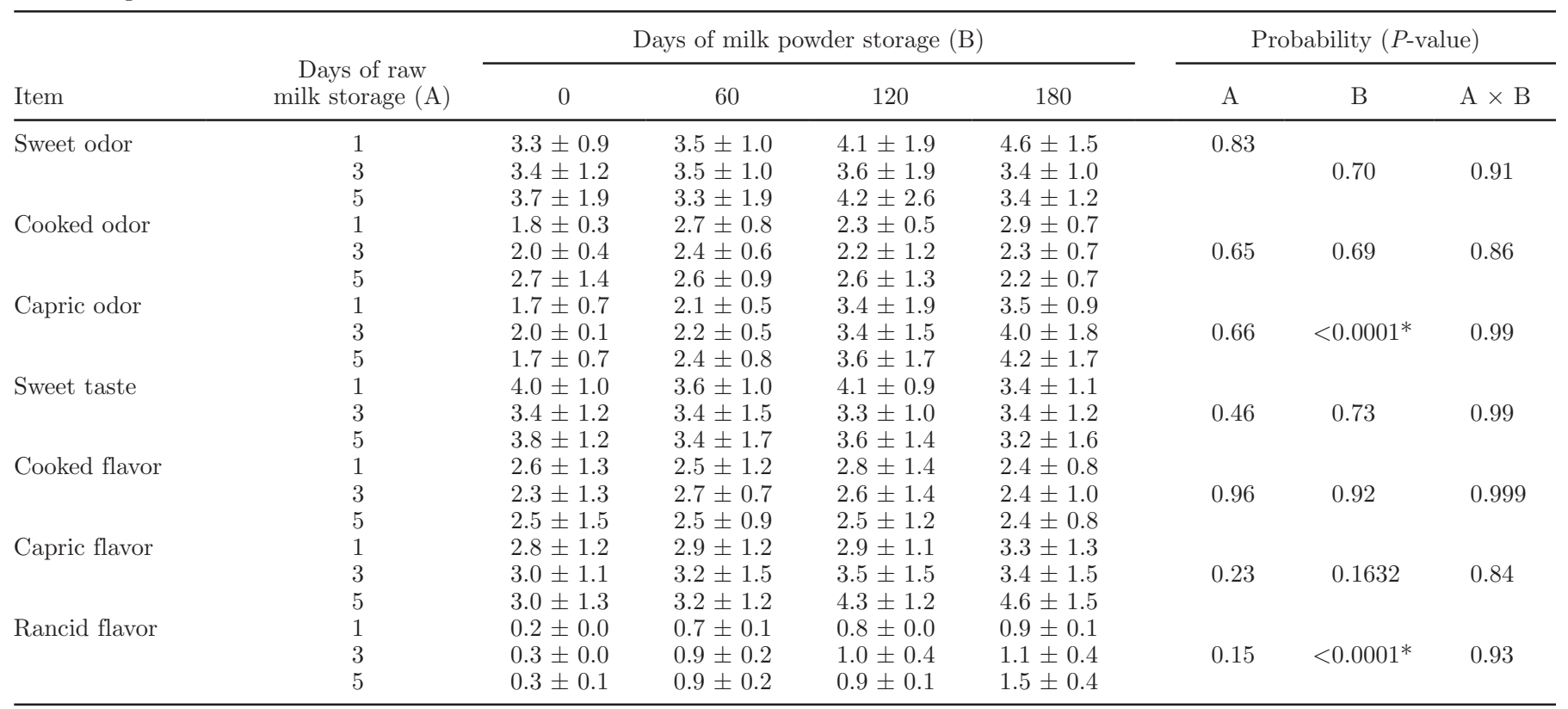

*Significant $(P<0.05)$.

correlated to biochemical and sensory changes in milk powder, such as increased FFA content and development of off-flavors that can reduce the shelf life of dairy products.

\section{CONCLUSIONS}

Our findings support that raw goat milk stored at $4^{\circ} \mathrm{C}$ enables the growth of lipolytic psychrotrophic bacteria. To maintain the quality of milk powder in relation to lipolysis during $180 \mathrm{~d}$ in the same storage conditions as used in this study, raw goat milk should not be kept at $4^{\circ} \mathrm{C}$ for more than $3 \mathrm{~d}$.

\section{ACKNOWLEDGMENTS}

The authors are grateful to The State of São Paulo Research Foundation (FAPESP, Brazil) for the financial support (grant 2006/61095-5).

\section{REFERENCES}

APHA (American Public Health Association). 2001. Compendium of Methods for the Microbiological Examination of Foods. 4th ed. APHA, Washington, DC.

AOAC International. 1995. Official Methods of Analysis of AOAC International. 17th ed. AOAC International, Washington, DC.

Baldwin, A. J., H. R. Cooper, and K. C. Palmer. 1991. Effect of preheat treatment and storage on the properties of whole milk powder: Changes in sensory properties. Neth. Milk Dairy J. 45:97-116.

Campos, L. R., R. de O. Treptow, and G. J. D. Soares. 1998. Influência da inertização com nitrogênio na vida de prateleira de leite em pó integral acondicionado em embalagens metalizadas flexíveis. Rev. Bras. Agrociência 4:130-137.

Castberg, H. B. 1992. Lipase activity. Bull. Int. Dairy Fed. 271:18-20.

Celestino, E. L., M. Iyer, and H. Roginski. 1997. The effects of refrigerated storage of raw milk on the quality of whole milk powder stored for different periods. Int. Dairy J. 7:119-127.

Champagne, C. P., R. R. Laing, D. Roy, A. A. Mafu, and M. W. Griffiths. 1994. Psychrotrophs in dairy products: Their effects and their control. Crit. Rev. Food Sci. Nutr. 34:1-30.

Chen, L., R. M. Daniel, and T. Coolbear. 2003. Detection and impact of protease and lipase activities in milk and milk powders. Int. Dairy J. 13:255-275.

Chilliard, Y., A. Ferlay, J. Rouel, and G. Lamberet. 2003. A review of nutritional and physiological factors affecting goat milk lipid synthesis and lipolysis. J. Dairy Sci. 86:1751-1770.

de Albuquerque Brasil, L. H., F. S. Wechesler, F. Baccari Júnior, H. C. Gonçalves, and I. A. Bonassi. 2000. Efeitos do estresse térmico sobre a produção, composição química do leite e respostas termorreguladoras de cabras da raça alpina. R. Bras. Zootec. 29:1632-1641.

De Jong, C., and H. T. Badings. 1990. Determination of free fatty acids in milk and cheese: Procedures of extraction, clean up, and capillary gas chromatographic analysis. J. High Resolut. Chromatogr. 13:94-98.

Deeth, H. C. 1993. Lipase activity and its effects on milk quality. Aust. J. Dairy Technol. 48:96-98.

Deeth, H. C., C. H. Fitz-Gerald, and A. F. Wood. 1975. A convenient method for determining the extent of lipolysis in milk. Aust. J. Dairy Technol. 30:109-111.

Delacroix-Buchet, A., and G. Lamberet. 2000. Sensorial properties and typicity of goat dairy products. Pages 559-563 in Proc. 7th Intl. Conf. Goats. INRA, Paris, France.

Diniz, A. C. P., M. B. Luiz, L. V. Gonzaga, M. M. Meier, S. Szpoganicz, and R. Fett. 2005. Comportamento da $\beta$-ciclodextrina adicionada ao leite de cabra submetido ao processo de desidratação por "spray dryer". Ciência Tecnol. Aliment. 25:197-201.

Dubeuf, J.-P., P. Morand-Fehr, and R. Rubino. 2004. Situation, changes and future of goat industry around the world. Small Rumin. Res. 51:165-173. 
Fekadu, B., K. Soryal, S. Zeng, D. Van Hekken, B. Bah, and M. Villaquiran. 2005. Changes in goat milk composition during lactation and their effect on yield and quality of hard and semi-hard cheeses. Small Rumin. Res. 59:55-63.

Kondyli, E., and M. C. Katsiari. 2002. Fatty acid composition of raw caprine milk of a native Greek breed during lactation. Int. J. Dairy Technol. 55:56-60.

Kondyli, E., C. Svarnas, J. Samelis, and M. C. Katsiari. 2012. Chemical composition and microbiological quality of ewe and goat milk of native Greek breeds. Small Rumin. Res. 103:194-199.

Lamberet, G., C. Degas, A. Delacroix-Buchet, and L. Vassal. 1996. Influence de caractères liès aux allèles $\mathrm{A}$ et $\mathrm{F}$ de la caséine as1 caprine sur la flaveur chèvre: Fabrications fromagères avec échange de proteins e matière grasse. Lait 76:349-361.

McCluskey, S., J. F. Connolly, R. Devery, B. O’Brien, J. Kelly, D. Harrington, and C. Stanton. 1997. Lipid and cholesterol oxidation in whole milk powder during processing and storage. J. Food Sci. 62:331-337.

Ministério da Agricultura do Abastecimento e da Reforma Agrária. 1996. Portaria 146: Regulamento técnico de identidade e qualidade de leite em pó. Diário Oficial da União, 48, Seção I:3985. Ministério da Agricultura do Abastecimento e da Reforma Agrária, Brazil.

Ministério da Agricultura e Pecuária. 1999. Portaria 56: Regulamento técnico de identidade e qualidade do leite de cabra. Diário Oficial da União, 234, Seção I:23-25. Ministério da Agricultura e Pecuária, Brazil.

Muir, D. D. 1996. The shelf-life of dairy products: Intermediate and long life dairy products. Int. J. Dairy Technol. 49:119-124.

Páez, R., N. Pensel, N. Sabbag, M. Taverna, A. Cuatrín, and C. Zalazar. 2006. Changes in free fatty acid composition during storage of whole milk powder. Int. J. Dairy Technol. 59:236-241.
Panfil-Kuncewicz, H., A. Kuncewicz, and M. Juśkiewicz. 2005. Influence of storage conditions on changes in the fat fraction of UHT milk. Pol. J. Food Nutr. Sci. 14:341-348.

Pereira, R. N., R. C. Martins, and A. A. Vicente. 2008. Goat milk free fatty acid characterization during conventional and ohmic heating pasteurization. J. Dairy Sci. 91:2925-2937.

Perin, L. M., P. M. Moraes, M. V. Vieira Almeida, and L. A. Nero. 2012. Interference of storage temperatures in the development of mesophilic, psychrotrophic, lipolytic and proteolytic microbiota of raw milk. Semina: Ciências Agrárias, Londrina 33:333-342.

Ribeiro, A. C., and S. D. A. Ribeiro. 2010. Specialty products made from goat milk. Small Rumin. Res. 89:225-233.

Samaržija, D., Š. Zamberlin, and T. Pogačić. 2012. Psychrotrophic bacteria and their negative effects on milk and dairy products quality. Mljekarstvo 62:77-95.

SAS Institute. 2002. User's Guide for SAS Software Navigator. 9th ed SAS Institute Inc., Cary, NC.

Silanikove, N., G. Leitner, U. Merin, and C. G. Prosser. 2010. Recent advances in exploiting goat's milk: Quality, safety and production aspects. Small Rumin. Res. 89:110-124.

Stapelfeldt, H., B. R. Nielsen, and L. H. Skibsted. 1997. Effect of heat treatment, water activity and storage temperature on the oxidative stability of whole milk powder. Int. Dairy J. 7:331-339.

Stone, H., and J. L. Sidel. 1985. Sensory Evaluation Practices. Academic Press, London, UK.

Vianna, P. C. B., E. H. M. Walter, M. E. F. Dias, J. A. F. Faria, F. M. Netto, and M. L. Gigante. 2012. Effect of addition of $\mathrm{CO}_{2}$ to raw milk on quality of UHT-treated milk. J. Dairy Sci. 95:4256-4262.

Zeng, S. S., S. S. Chen, B. Bah, and K. Tesfai. 2007. Effect of extended storage on microbiological quality, somatic cell count, and composition of raw goat milk on a farm. J. Food Prot. 70:1281-1285. 